\title{
O processo do trabalho como instrumento de tutela aos direitos fundamentais
}

O inadimplemento dos créditos trabalhistas por parte do empregador é tema de ampla divergência perante os tribunais e da própria doutrina, buscando-se o amparo e segurança jurídica na lei. O tema é de crucial relevância, visto que permite, de forma muito mais abrangente e contumaz a satisfação do crédito, abrangendo as possibilidades cabíveis para facilitar o adimplemento e impedir o inadimplemento de obrigações trabalhistas. Ao mesmo tempo, compreende a análise de alguns princípios constitucionais que harmonizam o embasamento e justificação da necessidade de uma tutela jurisdicional efetiva, e que fundamentam a sua devida aplicação no processo do trabalho, para que a demanda ofereça pelo menos a promessa de garantia ao trabalhador do recebimento de seu crédito, considerando as peculiaridades do credor. Visa analisar as possibilidades de responsabilização, caracterizando-as e diferenciando-as de acordo com a doutrina, a partir de uma seleção de bibliografia e documentos afins à temática e em meios físicos e na Internet, interdisciplinares.

Palavras-chave: Devedor insolvente; Direito do Trabalho; Modalidades de execução; Prestação jurisdicional.

\section{The work process as an instrument to protect fundamental rights}

The default of labor claims by the employer is a subject of wide divergence before the courts and from the doctrine itself, seeking legal protection and legal certainty. The topic is of crucial relevance, since it allows, in a much more comprehensive and recurrent way, the satisfaction of credit, covering the possible possibilities to facilitate the performance and prevent the default of labor obligations. At the same time, it comprises the analysis of some constitutional principles that harmonize the basis and justification of the need for effective judicial protection, and that justify its due application in the work process, so that the demand offers at least the promise of guarantee to the worker receipt of your credit, considering the peculiarities of the creditor. It aims to analyze the possibilities of accountability, characterizing and differentiating them according to the doctrine, based on a selection of bibliography and documents related to the theme and in interdisciplinary physical and Internet media.

Keywords: Insolvent debtor; Labor Law; Implementation modalities; Adjudication.

Topic: Direito do Trabalho e Processo do Trabalho

Reviewed anonymously in the process of blind peer.
Received: 20/05/2020

Approved: 18/08/2020
Vanessa Caroline Cardoso (iD

Universidade Regional do Noroeste do Estado do Rio Grande do Sul, Brasil

http://lattes.cnpq.br/0899046368343300

http://orcid.org/0000-0001-9814-5280

vanessa.c.cardoso21@gmail.com
Referencing this:

CARDOSO, V. C.. O processo do trabalho como instrumento de tutela aos direitos fundamentais. Scientiam Juris, v.8, n.2, p.32-49, 2020. DOI: http://doi.org/10.6008/CBPC2318-3039.2020.002.0003 


\section{INTRODUÇÃO}

O presente trabalho apresenta um estudo com enfoque à análise das ferramentas processuais a serem utilizadas para o resguardo do direito à efetividade do cumprimento da sentença judicial que defere créditos trabalhistas. Ao mesmo tempo, analisaram-se também as possibilidades jurídicas capazes de amparar tais causas, a fim de respaldar a devida tutela jurídica.

Muitas vezes, mesmo após terem percorrido o trajeto processual em busca da cognição de seu direito até a formação do título executivo judicial, ou mesmo sendo possuidor de um título executivo extrajudicial, o credor acaba não obtendo satisfeita a obrigação. Esses e outros casos fragilizam os direitos previstos na CLT, Constituição Federais e demais dispositivos normativos, podendo acarretar grande insegurança jurídica, econômica e social.

Nesse cenário, compreende-se que a crise econômica emergente afeta principalmente as pequenas empresas, no entanto, o inadimplemento é inaceitável e menos ainda que tal prática torne-se recorrente. É dever do empregador assumir o ônus e as variáveis decorrentes de sua atividade. Mais do que isso, a ele incumbe atender aos direitos e deveres para com os colaboradores de seu empreendimento, devendo ser resguardada a aplicabilidade de seus direitos.

Visto isso, vislumbrou-se indagar, principalmente, a importância do aparato constitucional e legislativo presente por detrás do desenvolvimento da demanda judicial instaurada pelo trabalhador, a fim de lhe apurar resultados válidos e eficazes. Por conseguinte, também se buscou demonstrar as possibilidades facilitadoras de que dispõe o exequente para que obtenha a satisfação de seu crédito.

Para a confecção deste trabalho foram efetuadas pesquisas bibliográficas mediante materiais físicos e digitais, visando adequar a pesquisa ao enfoque do tema, enriquecer a coleta de informações e permitir um aprofundamento no estudo. Revelando-se, nesse sentido, a importância da utilização dos métodos processuais cabíveis para a efetivação do devido cumprimento de sentença.

\section{DISCUSSÃO TEÓRICA}

\section{Princípios Constitucionais embasadores da Execução Trabalhista}

A execução em geral está amparada no Código de Processo Civil - CPC, que disciplina os dois tipos de execução existentes no ordenamento jurídico atualmente. Fundamenta, portanto, as diferenças cruciais existentes entre a execução fundada em título judicial, tratada como cumprimento de sentença, e a fundada em título executivo extrajudicial.

Entretanto, para que se possa mensurar a gravidade que se constitui ao trabalhador o não recebimento de seu crédito, existem princípios basilares previstos na Constituição Federal que elencam as máximas de observação obrigatória, desde o momento da propositura da ação, até o final de sua execução.

Nesse sentido, os princípios são normas basilares coativas e coercitivas que regem o ordenamento jurídico em sua totalidade, além de exercerem papel fundamental na fundamentação dos dispositivos legislativos. Portanto, trazem em si a essência da lei e a sua função se constitui na regulamentação da vida 
em sociedade.

Ao mesmo tempo em que exercem papel fundamental na efetividade das normas legislativas, possuem ligação entre si, no sentido de um complementar o outro e permitirem uma interpretação mais completa quando não isolados dos demais. Nesse sentido, a autora Guimarães (2003) destaca:

[...] um princípio está sempre se relacionando com os demais princípios, cabendo ao intérprete identificá-los e hierarquizá-los, de acordo com os valores que prevalecem em dado caso concreto e levando em conta todo o sistema do Direito positivo, uma vez que eles refletem a vontade do povo que foi apreendida pelo constituinte ao criar determina norma.

Visto isso, os princípios formam um sistema interligado de dispositivos que estendem a sua aplicação ao caso concreto, visando a adequação quando pertinente. Porém, os princípios basilares de hoje foram fruto do Estado Contemporâneo, cuja essência aflorou em meio a conflitos sociais e revoluções.

Nesse contexto, ressurge a importância de alguns princípios antigos, como o da proporcionalidade, que possui papel fundamental na conciliação entre a aplicação dos princípios e a lei em si. Em conformidade, lecionando sobre o tema, Cademartori (2004) explana:

[...] as normas e diretrizes da política estatal encontram-se permeadas por conceitos jurídicos indeterminados, tais como segurança jurídica, justiça social, interesse público - de acentuado conteúdo axiológico - os quais terminam por gerar um padrão de decisões judiciais, quando do conflito de interesses, baseado na ponderação de valores, sob a forma de princípios em colisão. Isto, entretanto, não invalida a existência de regras (leis em sentido estrito) as quais, sob a sua dimensão de generalidade, assegura a igualdade perante a lei com certo distanciamento de contextos mutáveis, aos quais soma-se um grau de abstração que acaba por conduzi-las a um princípio geral segundo o qual toda situação envolvendo condições de igualdade deve ter tratamento igual e toda situação envolvendo condições diferenciadas deve ter tratamento diferenciado.

Assim, referido princípio assume papel fundamental na ponderação de valores, levando em sua essência a busca pela justiça amparando-se na máxima aristotélica de que situações iguais, previamente reconhecidas na esfera judicial, merecem decisões semelhantes, para que não seja desencadeada a disparidade de decisões. Enquanto que, em casos de situações divergentes, inéditas na seara processual, o tratamento será divergente e relativo àquele caso concreto.

Essa última máxima, de que situações desiguais merecem tratamentos desiguais, fundamenta também os princípios aplicados no direito do trabalho, destacando entre eles, por exemplo, o princípio da proteção, que atribui desigualdades no processo, como a inversão do ônus da prova, para compensar a hipossuficiência econômica do trabalhador perante o empregador.

Entretanto, para destacar a importância inerente aos princípios, é de suma relevância individualizálos e classificá-los, dentre eles, os mais pertinentes ao Processo de Execução Trabalhista. Tratando de princípios constitucionais, eles norteiam os procedimentos judiciais, influem nas decisões e legislações, estando em posição hierárquica superior. A respeito do tema, o autor Bonavides (2006) destaca:

[...] no ponto mais alta da escala normativa, eles mesmos, sendo normas, se tornam, doravante, as normas supremas do ordenamento. Servindo de pautas ou critérios por excelência para avaliação de todos os conteúdos constitucionais, os princípios, desde sua constitucionalização, que é, ao mesmo passo, positivação no mais alto grau, recebem, como instância máxima, categoria constitucional, rodeada do prestígio e da hegemonia que se confere às normas inseridas na Lei das leis. 
Dentre os princípios basilares da ordem constitucional destaca-se o princípio do acesso à justiça, reconhecido também como direito de ação, por tratar-se do direito que possui o indivíduo de ter dirimido os seus conflitos por uma instância superior, e ter retirado de si o ônus de fazer justiça com as próprias mãos.

O autor Cappelletti et al. (2002) define o referido princípio como:

[...] serve para determinar duas finalidades básicas do sistema jurídico - o sistema pelo qual as pessoas podem reivindicar seus direitos e/ou resolver seus litígios sob os auspícios do Estado. Primeiro, o sistema deve ser igualmente acessível a todos; segundo, ele deve produzir resultados que sejam individual e socialmente justos.

O jurista italiano entende como revolucionárias as relações sociais, que acabaram transformando, inclusive, o próprio caráter dos direitos humanos. Aos poucos, foi se abandonando cada vez mais a ideia do Estado Individualista e se assumiu uma postura mais coletiva, cujas relações com o Estado não se restringem somente aos interesses individuais, mas também aos coletivos. $\mathrm{O}$ que consolida a busca maior por um Estado Social, que preza pela efetivação do direito à educação, saúde e bem-estar e acaba por afirmar de fato o direito de ação. Seguindo a mesma linha, Porto (2006) explana:

À medida que os direitos fundamentais vão evoluindo de uma concepção forma e individual para outra democrática e substancial; na proporção em que o Direito começa a interrelacionar-se com outras ciências sociais, como a Sociologia, a Ciência Política e a Economia, admitindo a existência de desigualdades que se fazem sentir no plano econômico, social, cultural e técnico; conforme o Estado foi abandonando aquele viés liberal abstencionista, evoluindo para um Estado gerador de políticas públicas niveladoras das desigualdades econômicas, geradoras de homogeneidade social, sem dúvida, a possibilidade de acesso efetivo à justiça firmou-se como direito fundamental do cidadão na perspectiva individual ou coletiva, que o Estado Democrático de Direito deve garantir, como decorrência inarredável do contrato social.

Entretanto, embora faça menção a um direito fundamental, vêm sendo muito relativizado a casos individuais que tratam de assuntos já decididos em outras demandas. Mesmo após as mudanças ocorridas, ainda é emergente uma intervenção mais ativa por parte do Estado, visto que ainda assombram os tribunais demandas individuais repetitivas, que tratam dos mesmos temas e visam soluções semelhantes.

Convém destacar, portanto, que o direito de ação vem para garantir a efetivação de ter a devida reparação quem sofreu alguma ameaça ou lesão ao seu direito, e não para discutir direitos previamente reconhecidos em outros julgados ou para simbolizar vingança. Deve servir como uma segurança jurídica e não como alvo de discussões já previamente consolidadas.

Ao mesmo tempo em que é de suma importância a efetivação do direito de ação, está correlacionado a ele o direito ao devido processo legal. Assim, o referido princípio rege que todos os conflitos obedeçam aos mecanismos jurídicos e desenvolvimento do processo estabelecidos em lei. Em relação ao tema, os autores Cintra et al. (1995) conceituam:

[...] o conjunto de garantias constitucionais que, de um lado, asseguram às partes o exercício de suas faculdades e poderes processuais e, do outro, são indispensáveis ao correto exercício da jurisdição. Garantias que não servem apenas aos interesses das partes, como direitos públicos subjetivos (ou poderes e faculdades processuais) destas, mas que configuram, antes de mais nada, a salvaguarda do próprio processo, objetivamente considerado, como fator legitimante do exercício da jurisdição.

Mas o princípio não se limita a apenas respaldar o cumprimento correto do caminho processual, mas também verifica a necessidade da efetivação de outros princípios, como o contraditório e a ampla defesa, a 
igualdade e dignidade entre as partes, assim como a produção de provas e o livre convencimento do juiz.

Nesse sentido, merece destaque o princípio do contraditório e da ampla defesa, já que também estão expressos na Constituição Federal. Pelo princípio, as partes possuem o direito de não somente apresentar defesa em relação aos fatos trazidos, mas de serem representadas por um advogado, trazerem a sua versão dos fatos, produzirem provas, apresentarem a reconvenção e demonstrarem a sua inocência.

O autor Portanova (2005) assim complementa a conceituação do princípio: "dinamiza a dialética processual e vai tocar, como momento argumentativo, todos os atos que preparam o espírito do juiz.". Assim, o contraditório e a ampla defesa permitem que as partes influam mais diretamente no convencimento do juiz, para que se possa chegar o mais próximo da verdade real dos fatos.

No tocante aos princípios do processo do trabalho, a doutrina diverge quanto à existência de princípios específicos para o ramo, já que na grande maioria dos casos se aplicam princípios constitucionais ou princípios do processo civil. Sobre o tema, Saraiva (2005) explana:

A divergência citada é natural, pois o processo do trabalho é neófito, incompleto, e assistemático, ainda utilizando, subsidiariamente, boa parte das normas do processo civil, carecendo de uma legislação mais abrangente e complexa que defina seus próprios princípios, o que acaba por fazer com que os autores transportem para o campo trabalhista os princípios gerais do processo civil, adequando-os às peculiaridade e particularidades do processo do trabalho.

Mesmo após a celebração da reforma trabalhista em 2017, muitos pontos permanecem carecendo de complementação. Houve muitas mudanças, inclusive, no tocante aos princípios, foi ampliada a extensão da aplicação dos princípios relativos ao processo comum e houve a implementação de dois novos. A partir da leitura do artigo 8o da Lei 13.467 de 2017, Schiavi (2018) explana:

Aqui, houve alterações profundas na sistemática de aplicação do direito comum, com ênfase ao direito civil, no campo do direito do trabalho. Houve supressão do requisito da compatibilidade como barreira de contenção para aplicação do direito comum às relações trabalhistas, bastando o requisito da omissão.

Nesse sentido, o que já era uma aplicação costumeira se tornou norma de fato ainda mais branda. Para caracterizar a sua aplicação, basta que exista a simples compatibilidade, já nem é mais necessária a omissão de norma expressa. De acordo com a interpretação, Schiavi (2018) explana:

De nossa parte, a alteração não é oportuna, pois o Direito do Trabalho é ramo autônomo da ciência jurídica e tem sua principiologia própria, como eixo central o princípio da proteção ao trabalhador. Já o direito comum, parte do princípio da igualdade de partes que figuram em determinada relação jurídica. A alteração do parágrafo primeiro do artigo 8으, da CLT deve ser compatibilizada com os princípios, regras e singularidades do Direito do Trabalho. Se norma civilista conflitar com a trabalhista, mesmo havendo omissão da CLT, ela não deverá ser aplicável.

Assim, visto que o direito civil tem o seu ramo mais embasado na igualdade jurídica entre as partes, e no direito do trabalho a prevalência é do princípio da proteção, em muitas relações de trabalho o trabalhador pode vir a ser prejudicado por conta de uma interpretação mais igualitária entre partes, sendo que na verdade o que deveria prevalecer seria uma aplicação do que é mais benéfico ao trabalhador.

Isso também é resultado de outra alteração, a inserção do princípio da intervenção mínima, que possibilita uma negociação mais livre entre o trabalhador e empregador, inclusive sobre matérias anteriormente proibidas. Sobre o tema, Assis (2017): 
[...] em que pese a prevalência do negociado já existisse no ordenamento jurídico brasileiro, essa posição de prevalência era vislumbrada uma vez estabelecidos patamares superiores ao direito mínimo estabelecido em lei, o que se tornava situação extremamente vantajosa para o trabalhador. Todavia, a inserção do artigo 611-A [e 620] na Consolidação das Leis Trabalhistas, veio justamente no sentido oposto, uma vez que a partir da redação desse dispositivo fica também permitida a redução de direitos e benefícios assegurados em diploma legal, de maneira que a convenção e os acordos coletivos perdem seu papel de fonte suplementar do Direito do Trabalho para assumir um papel de regulador de interesses e objetivos econômicos.

Assim, parte da segurança jurídica que era repassada a partir da regra do legislado sobre o negociado cai por terra a partir da inovação. Alguns pontos ainda ficaram protegidos, aqueles dispostos no rol do artigo 611-B da CLT, como a remuneração do trabalho noturno superior ao diurno e a remuneração ao serviço extraordinário como superior em pelo menos $50 \%$ de acréscimo sobre a hora. Tais disposições possuem expressão taxativa, estando impedidos de negociação somente aqueles direitos dispostos no referido artigo.

Nesse sentido, percebe-se que os direitos que restam respaldados em lei não garantem por si que sejam asseguradas as garantias essenciais para se ter boas condições de trabalho. Foram suprimidas muitas garantias, tornando-se, assim, um ônus incumbido ao trabalhador de buscar a negociação sobre elas. Assim explana Assis (2017):

A prevalência do negociado sobre o legislado, conforme disposta no texto dos artigos 611 - A e 611-B da CLT, evidencia o propósito escancarado de reduzir direitos da classe obreira, sem qualquer tipo de salvaguarda que permita aos trabalhadores resistirem contra as investidas dos empregadores. Em verdade, verifica-se real contrariedade aos objetivos fundamentais do Estado e promove o retrocesso social, e constitui, a rigor, um desprestígio à negociação coletiva entre empregados e empregadores, e aos acordos e às convenções coletivas de trabalho.

Assim, com a prevalência do negociado sobre o legislado, aumentam as possibilidades de submissão do trabalhador às condições que o seu empregador julgar pertinentes. As disposições do referido artigo deveriam mencionar apenas alguns casos em que seria permitida a negociação, mantendo protegidas, assim, algumas das prerrogativas alcançadas com tanto pudor pelos trabalhadores.

Os referidos artigos trouxeram, na verdade, o sentido inverso, fomentando a negociação entre trabalhador e empregador ainda mais restrita, já que um desacordo, ou a falta de concordância por parte do trabalhador, pode resultar no término da relação de trabalho, ou até mesmo impedir que ela se inicie.

Outro reflexo da alteração da lei é a relativização da aplicação do princípio de proteção ao trabalhador. Nesse sentido, para melhor compreender o aludido princípio, faz-se necessária à sua conceituação, bem como a sua subdivisão, visto que ele se divide em três modalidades. Nas palavras de Seabra Neto (2019):

Este princípio tem como objetivo principal garantir proteção à parte considerada hipossuficiente, em suma maioria dos casos o trabalhador, cujo objetivo é assegurar uma igualdade jurídica entre os sujeitos da relação, permitindo que alcance uma igualdade jurídica.

Assim, em uma classificação mais branda, compreende-se por princípio de proteção ao trabalhador aquele que visa garantir um tratamento diferenciado, trazendo a hipossuficiência do trabalhador à tona, para assegurar a igualdade jurídica. Sobre a subdivisão existente, Seabra Neto (2019) menciona: 
O princípio protetivo divide-se em três, quais sejam: 1) Princípio in dubio pró-operário: ao analisar determinada regra trabalhista, o intérprete opta pela aplicação da interpretação mais favorável ao trabalhador.

[...] 2) Princípio da utilização da norma mais favorável: ao analisar duas ou mais normas para determinado litígio, aplica-se aquela mais favorável ao trabalhador, independentemente de sua posição hierárquica. Vale ressaltar que este princípio foi mitigado em razão do art. 611A, da CLT, o qual dispõe que o negociado prevalece sobre o legislado, e também o art. 620 do mesmo diploma, o qual dispõe que o acordo coletivo prevalece sobre convenção coletiva.

3) Princípio da condição mais benéfica: as condições mais vantajosas estipuladas no contrato laboral ou no regulamento da empresa prevalecerão, independentemente da elaboração de nova norma sobre o mesmo tema.

Ademais, perante a classificação percebe-se a preocupação, que não é recente, em proteger o empregado de entendimentos e situações que possam lhe prejudicar ou o impedir de deter o seu direito efetivado. Na primeira classificação, o intérprete usará a interpretação para aplicar a regra mais favorável ao empregado. No segundo caso, analisando duas ou mais normas dentro de um mesmo litígio, aplicará a mais favorável ao trabalhador. Por último, sobressairá a condição mais benéfica ao trabalhador.

O artigo 444 da CLT traz força ainda maior para a expressão legislativa prevista no artigo 611-A, já que reforça o entendimento da preponderância do negociado sobre o legislado. Permite a livre disposição e estipulação, ressalvado, apenas, o rol taxativo trazido no artigo 611-B.

Assim, a máxima existente no direito do trabalho de que deve prevalecer a decisão que mais beneficiará ao trabalhador assume interpretação relativizada, graças à inserção dos artigos 444 e $611-A$ da CLT. Visto isso, é fundamental a preponderância das regras contidas nos princípios, a fim de permitir a aplicabilidade das disposições normativas em favor das previsões constitucionais, efetivando-se o real objetivo contido na lei ao criar as normas regentes de tais adequações.

\section{A relevância da efetividade das Decisões Judiciais Trabalhistas}

Diante do presente exposto, analisadas as prerrogativas de tutela à execução, constata-se que o elemento central dos princípios se funde na busca pela efetivação dos direitos fundamentais dos trabalhadores. Podendo-se dizer, nesse sentido, que a sua existência se justifica para que sejam asseguradas as garantias constitucionais.

Assim, necessariamente, os princípios basilares do processo do trabalho devem estar de acordo com os princípios do direito do trabalho, e ambos deverão estar alinhados em direção aos direitos fundamentais previstos na Constituição Federal, para que possam atingir a sua maior finalidade. Nesse sentido, Rodrigues et al. (2016) elencam:

A ideia central que se encontra nessa relação entre Constituição e processo está na necessidade de preservar valores do Estado Democrático de Direito e garantir adequado, efetivo e célere acesso à Justiça, interpretando, aplicando e também produzindo legislativamente o arcabouço normativo infraconstitucional a partir desses fundamentos valorativos [...].

Ocorre que, intrinsecamente relacionado ao tema, cumpre destacar uma garantia essencial para que sejam concretizadas essas prerrogativas, o direito de acesso à Justiça. Constitui-se em elemento fomentador 
não somente da instauração da execução, mas do seu devido cumprimento, a fim de atingir a satisfação em si. Em outras palavras, tal fundamento se justifica como sendo a razão por detrás da existência desses princípios constitucionais.

Ressaltando a explanação anterior acerca dos princípios e da sua essência, perfaz-se que é nessa ideia que se centraliza a razão de ser e de existir de uma ação judicial. Nesse ponto, no âmbito trabalhista, a sua razão de existir consiste em uma lesão ou descumprimento de alguma das partes daquilo que fora convencionado no contrato de trabalho.

Isso enaltece fortes diferenciações entre a instauração pelo procedimento comum e pelo procedimento trabalhista, visto que ao trabalhador o impacto ocasionado por uma lesão restará em consequências nefastas. Isso tendo em vista que a ele pertence a posição de parte vulnerável, se fazendo uma tutela efetiva e o seu devido cumprimento.

Ademais, a necessidade urgente pela eficácia imediata, é embasada em suas características essenciais, sendo que a efetivação não recai somente sobre a vulnerabilidade do trabalhador. É importante destacar a função social do trabalho, mais especificamente dos rendimentos provenientes dele, possuem caráter alimentar, o que reforça esse dever de cumprimento.

Nesse sentido, Araújo (2018) ressalta:

Em primeiro lugar, a eficácia imediata se justifica em razão da notável diferença de poder entre as partes da relação de emprego. Parece evidente que a diferença de poder existe nas relações entre consumidores e fornecedores, e entre clientes e instituições financeiras; porém, ela existe, por definição, e é ainda mais notável nas relações entre empregados e empregadores. De fato, a relação de emprego se caracteriza justamente pela subordinação do empregado e pelo poder diretivo do empregador, os quais são vistos como verso e anverso do mesmo fenômeno. A subordinação do empregado ao poder do empregador é nota conceitual da relação jurídica de emprego (diferentemente do que ocorre na relação de consumo, por exemplo, que não tem a subordinação ou sujeição como nota conceitual).

Nesse sentido, cumpre destacar que é essa referida subordinação do trabalhador que o induz a venerar os ditames concedidos pelo empregador na esfera laboral, assim como o dever de respeito, pronto atendimento, educação, dedicação e esforço. Portanto, apenas com a análise desse único requisito já se demonstra a eminente supremacia existente entre os sujeitos, própria natureza dessa relação jurídica. Em relação ao tema, leciona Leite (2016):

Como as relações de trabalho subordinado são marcadas pela desigualdade entre os particulares, de um lado o empregador, que detém o poder empregatício (econômico, regulamentar, diretivo e disciplinar), e do outro o empregado, hipossuficiente e vulnerável, parece-nos inegável a plena aplicação da eficácia horizontal dos direitos fundamentais nas relações empregatícias.

Ademais, frise-se, que além de tal requisito, a observância de tais fundamentos se legitima em outro quesito, o caráter alimentar das verbas trabalhistas. É de tamanha monta tal requisito, que a própria Constituição Federal dedicou artigo específico, que elenca quais títulos ela se estenderá, e a sua ordem de pagamento. Assim prescreve:

Art. 100. Os pagamentos devidos pelas Fazendas Públicas Federal, Estaduais, Distrital e Municipais, em virtude de sentença judiciária, far-se-ão exclusivamente na ordem cronológica de apresentação dos precatórios e à conta dos créditos respectivos, proibida a designação de casos ou de pessoas nas dotações orçamentárias e nos créditos adicionais 
abertos para este fim.

$\S 1$ 으 Os débitos de natureza alimentícia compreendem aqueles decorrentes de salários, vencimentos, proventos, pensões e suas complementações, benefícios previdenciários e indenizações por morte ou por invalidez, fundadas em responsabilidade civil, em virtude de sentença judicial transitada em julgado, e serão pagos com preferência sobre todos os demais débitos, exceto sobre aqueles referidos no $§ 2$ 을 deste artigo. (BRASIL, 1988)

Outrossim, aqueles títulos de natureza alimentícia são compreendidos como provenientes de salários, rendimentos, proventos, constituindo patrimônio mínimo necessário à sua subsistência e para que sejam atendidas as suas necessidades vitais básicas. A máxima é também resguardada pelos artigos 60 e 7ำ da Carta Magna, cujos incisos foram dedicados aos direitos inerentes à classe trabalhadora.

Nesse diapasão, é pacificamente reconhecido o caráter alimentar das verbas e créditos trabalhistas dentre os doutrinadores, possuindo, assim, inclusive ordem preferencial em sua execução. Devendo, nesse sentido, ser reconhecida a relevância crucial de uma decisão judicial célere e proveitosa.

Para que seja atendido tal resultado, mais do que respeitar as garantias efetivadas na carta magna, antes de tudo, é fundamental que a tutela jurisdicional adequada seja oferecida ao ofendido, no intuito de elidir a crise jurídica que os levou ao processo. Portanto, não deve proceder adstrita à mera procedimentalização da jurisdição, tampouco à promulgação de uma decisão reduzida à resolução do mérito. Sobre o tema, Dinamarco (2010, citado por ARAÚJO, 2018):

A tutela jurisdicional, assim enquadrada no sistema de proteção ao homem em relação a certos valores, não se confunde com o próprio serviço realizado pelos juízes no exercício de uma função estatal. Não se confunde com a jurisdição. A tutela é o resultado do processo em que essa função se exerce. Ela não reside na sentença em si mesma como ato processual, mas nos efeitos que ela efetivamente produzir fora do processo e sobre as relações entre pessoas. No processo ou na fase executiva tutela só haverá quando o titular do direito tiver obtido o bem desejado. No cognitivo o momento tutelar depende da espécie de crise jurídica a debelar e, portanto, da natureza e eficácia da sentença que acolher a pretensão daquele que tiver razão. As crises das situações jurídicas e as de certeza são desde logo debeladas pela própria sentença (constitutiva ou meramente declaratória, conforme o caso), dando-se desde logo a tutela; mas as de adimplemento perduram depois da sentença condenatória, e a tutela efetiva só poderá advir como fruto da execução forçada.

Outrossim, nem sempre as vias processuais são utilizadas como ferramentas destinadas a solucionar controvérsias. Entretanto, por vias das vezes, são expressas por fórmulas e demonstrativos isentos de teor e incoerentes à finalidade do ato processual. E é nesse cenário que ocorre a inversão dos valores, com a estima da via em prejuízo à finalidade do designo.

Conquanto, acrescente-se, tal tutela vai além do transcurso da ação e da sentença resolutória de mérito do caso. Comumente, na grande maioria dos casos, a mera indicação da letra fria da lei por meio da decisão se mostra insuficiente para atender ao objeto principal da ação, qual seja a tutela ao direito violado.

Corriqueiramente, justifica-se a expressão a partir do posicionamento da parte contrária, que, apesar do reconhecimento do direito nos moldes do caso concreto pela prolação da sentença, poderá prejudicar o seu devido cumprimento. Ademais, o tema supracitado comporá abordagem do próximo item. 


\section{A pertinência da eficácia da execução trabalhista}

Vistos alguns requisitos, e caracterizada a sua crucial relevância acerca do processo de execução trabalhista, constitui interesse do presente fazer menção da eficácia da execução trabalhista. Não basta que ao credor seja desferida uma sentença e que seja consagrado um título executivo judicial, se, ao final, ele se deparar com artimanhas do devedor capazes de esquivá-lo de tal obrigação.

Para que seja a ele consagrada a real e efetiva tutela jurisdicional, é necessário que a ele seja conferida a satisfação de seu crédito. Nesse ponto, tendo em vista que o devedor muitas vezes cria óbices para o descumprimento, comprometendo o resultado útil do processo.

Fundamentalmente, a respeito dos alicerces constitucionais regentes do processo trabalhista, na prática atual eles vêm representados por vultosos aspectos patrimonialistas. E, nesses casos, acaba por suscitar discussões mais voltadas ao quantum deberator, e afastar a preocupação com a efetiva lesão sucedida e analisada.

Os conflitos acabam pairando-se à apuração de valores e formalização de dívidas monetárias, sem que ao menos sejam fomentadas questões como a construção histórica desses direitos e a sua significância para a preservação da saúde dos trabalhadores. Assim, nesses casos, a demanda acaba por desassociar-se do axioma elementar cuja tutela perfaz a ordem de sua incumbência.

Entretanto, a sua aplicação restringe-se ao campo da execução, que compreenderá menções específicas. Igualmente, o processo do trabalho acha-se primordial para a exequibilidade do próprio direito material, possibilitando que a previsão normativa trabalhista esteja apta a engendrar proveito.

No entanto, constata-se no cenário atual a baixa produtividade e o crescente inadimplemento por parte do devedor em relação aos referidos créditos. Conquanto, a fim de referenciar seu entendimento acerca do tema, Claus (2019) explana:

A crueldade com a qual o credor podia tratar o devedor não encontra qualquer possibilidade de repristinação diante da consagração dos direitos fundamentais. Contudo, uma reflexão consequente acerca da baixa efetividade da execução passa pelo reconhecimento de que o potencial de coerção na execução aumenta quando se combina a execução de natureza patrimonial, com aquela de natureza pessoal, em determinadas situações, caracterizadas quando o crédito goza de privilégio jurídico especial, como é o caso da pensão alimentícia do direito de família e como parece deva ser compreendido também o caso do crédito trabalhista, cuja natureza alimentar é reconhecida de forma pacífica (CF, art. 100, § 1으).

O autor defende a tese de que a eficácia da execução está atrelada, muitas vezes, à coerção imposta em face do executado, já que a penalidade imposta traz consequências ainda mais temorosas do que aquelas aplicadas sobre o patrimônio. Em um trecho, Claus (2019) inclusive traz como exemplo a penalidade imposta ao devedor de alimentos, que extrapola os limites do patrimônio e acarreta em prisão civil. O devedor se obriga a pagar em virtude da sanção que Ihe é imposta, ela opera como fator de eficaz persuasão.

Ademais, de acordo com a tese, grande parte dos resultados desastrosos na seara trabalhista constituem resultância da queda do potencial coercitivo ocasionado pela alteração da natureza da execução de pessoal para patrimonial. Destaca, ainda, que a eficácia se amplia quando goza o crédito de privilégio jurídico especial, assim como o é a pensão alimentícia, cujo caráter também é alimentar. 
Nesse diapasão, considerando as peculiaridades da sentença trabalhista, que trata de deferir ao credor o direito ao recebimento de créditos alimentares, o tratamento diferenciado deverá ser resguardado. Portanto, acaba por refletir em normas processuais específicas que visam assegurar algumas das garantias constitucionais, e efetivar o seu cumprimento.

Sobre a execução do título judicial, assim ressalta Gonçalves (2018):

A efetividade de execução exige que, em caso de inadimplemento do devedor, o credor consiga alcançar resultado o mais próximo possível daquele que obteria caso a obrigação tivesse sido satisfeita espontaneamente. Se o devedor assumiu a obrigação de fazer, não fazer ou entregar coisa, a execução deve assegurar-lhe meios para exigir o cumprimento específico da obrigação, reservando a conversão para perdas e danos apenas para a hipótese de o cumprimento específico tornar-se impossível, ou para quando o credor preferi-la.

Em consonância com as especificidades das leis trabalhistas, a legislação processual trabalhista prevê, inclusive, a possibilidade de execução de ofício da sentença, nos casos em que as partes não estiverem representadas por advogado nos termos do artigo 878 da CLT. O preceito contraria o princípio da inércia, que determina a dinâmica do sistema civilista, que, no caso expresso em lei, independentemente da iniciativa da parte, as decisões sejam cumpridas.

Nesse sentido, Claus (2019) explana:

Amparada nos ensinamentos de Liebman, a doutrina de Manoel Antônio Teixeira Filho está assentada na precisa consideração de que a situação de igualdade das partes só se verifica no processo de conhecimento, porquanto o princípio do contraditório lhe é essencial. No processo de execução, não há mais equilíbrio entre as partes, caracterizando-se uma situação de regular preeminência do credor e de simétrica sujeição do devedor ao comando do título executivo judicial. Ao devedor resta suportar a execução que se realiza em seu desfavor, podendo pretender, unicamente, seja observada a lei na execução forçada a que deu causa pela omissão em cumprir a obrigação espontaneamente.

A aludida distinção denota um dos casos previstos na Consolidação das Leis do Trabalho em que houve a preocupação em se amoldar o procedimento celetista à especificidade do apanágio material tutelado. Visto isso, considerando que na fase executiva já não se está mais presente a igualdade entre as partes, o cumprimento da execução menos gravosa deve ser relativizado na seara trabalhista, para que a parte hipossuficiente e vulnerável não reste prejudicada.

Em explanação a respeito do tema, Claus (2019) assevera:

Nada obstante reste ao executado unicamente a pretensão de que execução observe os termos da lei, o fato é que a execução, regra geral, não é levada a sério pelo executado. Mais do que pretender que a execução observe os termos da lei, tem sido reconhecido ao executado, na prática, opor-se à execução de forma contumaz. Não há preocupação do executado em cumprir a obrigação. Esse dever desnaturou-se. Parece que há apenas o direito de resistir à execução. Para isso, utilizam-se todos os meios procedimentais disponíveis. E esses meios procedimentais são demasiados. É cada vez mais restrito o espaço para falar do dever do executado de cumprir a obrigação. Se ele tem direito de cumprir a obrigação nos termos legais, ele também tem o simétrico dever de cumprir a obrigação nos termos legais. Mas a nossa cultura parece ter deformado o direito de resistir à execução, quase que anulando a força moral do dever de cumprir a obrigação.

E, assim, consonantemente ao tema, é possível compreender que, na verdade, a relutância do devedor em adimplir a obrigação transfigurou-se em protótipo, e não mais ressalvas aplicáveis em sentido estrito. Na prática jurídica, prevalece, o entendimento de que as obrigações contidas na decisão não o serão 
por hora satisfeitos assim que proferidas, mas que, o serão se não obtiver êxito em suas tentativas de esquivar-se.

A tratativa legislativa refere que, caracterizando-se a permanência de mais de um modo para que o credor execute o título, cumpre a juízo acolher aquele menos gravoso ao devedor. No entanto, é crucial que integrem o procedimento a pluralidade de vias, havendo, assim, a possibilidade da prestação de modos diversos sem que acarretem em prejuízo à entrega da prestação jurisdicional.

Complementando a afirmação, Claus (2019): “... só se deve falar em adoção de meios menos graves desde que isso não signifique abdicação do direito do credor de ver satisfeita de forma eficiente a obrigação da qual é titular".

Outrossim, é necessário que seja reiterado que o princípio parte de uma acepção civilista, cujas partes encontram-se em posição hierárquica diversas. Na processualística civilista, o executado acha-se em condição econômica ínfera em relação ao exequente. Na seara trabalhista a sistemática é adversa, visto que o exequente é quem ocupa posição de hipossuficiência econômica em relação ao executado.

Reiteradamente, tal qual explicita o artigo 5 으 da Lei de Introdução às normas do Direito Brasileiro, 0 que deve prevalecer são os fins sociais da aplicação da lei, cabendo a análise da conjunção fática do caso em que o direito será aplicado. E, assim, deve ser levado em consideração que à parte hipossuficiente cabem condições econômicas desfavoráveis, que são incompatíveis com a delonga processual. Tal protelação, ao longo do processo, poderá importar na aceitação de um acordo prejudicial.

Com efeito, ao empregado resta posição de inferioridade econômica, cuja necessidade o impede de expectar durante longo período a finalização do trâmite processual. É nesse cenário que abarca grande consistência a observação de Schiavi (2010): “... no conflito entre normas que disciplinam o procedimento executivo, deve-se preferir a interpretação que favoreça o exequente".

Assim, considerando a hipossuficiência do trabalhador, o caráter alimentar do crédito resta suficientemente demonstrado que, havendo tal diferenciação entre o empregador e o trabalhador como fora explicitada, não há o que se falar em execução comum, tal qual como ocorre no processo civilista.

\section{Classificação Doutrinária das modalidades de execução}

Para que sejam compreendidas as modalidades possíveis de execução em face de um devedor solvente se faz necessária a conceituação dos títulos executivos e da forma que está disciplinada a matéria. No Direito do Trabalho, os artigos 769 e 889 da CLT, tratam do princípio primordial, o da subsidiariedade, que permite a aplicação do Código de Processo Civil nos casos em que a CLT for omissa. Nesse sentido, explana Marques (2018):

O artigo 769 da CLT dispõe que 'nos casos omissos o direito processual comum será fonte subsidiária do direito processual do trabalho, exceto naquilo em que for incompatível com as normas deste Título'. Referida regra tem aplicação somente na fase de conhecimento ao colocar o CPC como fonte subsidiária primeira do processo do trabalho. Já na fase de execução no processo do trabalho, a regra de aplicação da lei subsidiária é aquela prescrita no artigo 889 da CLT, que afirma que 'aos trâmites e incidentes do processo de execução são aplicáveis, naquilo em que não contravierem ao presente Título, os preceitos que regem o processo dos executivos fiscais para a cobrança judicial da dívida da Fazenda Pública 
Federal'.

Desse modo, como sabemos, a lei estabelece a regra específica a se aplicar tanto na fase de conhecimento quanto na execução. $\mathrm{E}$ há em comum $\mathrm{n}$ aplicação de ambas as leis o requisito da omissão pela CLT, o que desde logo exclui a aplicação de norma subsidiária quando aquela disciplinar a matéria.

Visto isso, em consonância com o princípio, a Consolidação das Leis do Trabalho possui um capítulo próprio com disposições referentes à instauração da execução e faz referência aos artigos do CPC que dispõem da execução no Processo Civil. Assim, o artigo 876 da CLT inicia o capítulo fazendo referência aos títulos que serão executados e das disposições que serão seguidas. Assim elenca:

Art. 876 - As decisões passadas em julgado ou das quais não tenha havido recurso com efeito suspensivo; os acordos, quando não cumpridos; os termos de ajuste de conduta firmados perante o Ministério Público do Trabalho e os termos de conciliação firmados perante as Comissões de Conciliação Prévia serão executada pela forma estabelecida neste Capítulo. (BRASIL, 1943)

Parágrafo único. A Justiça do Trabalho executará, de ofício, as contribuiç̃ões sociais previstas na alínea a do inciso I e no inciso II do caput do art. 195 da Constituição Federal, e seus acréscimos legais, relativas ao objeto da condenação constante das sentenças que proferir e dos acordos que homologar.

Assim, serão títulos executivos judiciais as sentenças ou acórdãos que reconheçam obrigação de fazer, de não fazer, de entregar coisa ou de pagar quantia certa. Da mesma forma, complementam a classificação, as decisões que homologam acordo entre as partes e que tenham conteúdo obrigacional e os créditos previdenciários decorrentes de sentenças ou acórdãos condenatórios ou homologação de acordos que contenham obrigação de pagar quantia certa.

Para a autora Marques (2019) as contribuições sociais poderão ser executadas por iniciativa própria do juiz competente, já que possuem natureza tributária e serão destinadas à manutenção da previdência social. Assim, em decorrência de sua destinação e caráter público, a sua arrecadação eficaz possui alta importância para o melhor funcionamento do órgão.

Quanto aos títulos executivos extrajudiciais, são reconhecidos perante a justiça do trabalho os termos de compromisso de ajustamento de conduta (TAC) firmados perante o Ministério Público do Trabalho, os termos de conciliação celebrados perante a Comissão de Conciliação Prévia e as Certidões de Dívida Ativa (CDA) decorrentes das multas aplicadas aos empregadores pelos órgãos de fiscalização do trabalho.

A classificação é reforçada pelo parágrafo único do artigo 831 da CLT, que faz referência aos termos de conciliação lavrados, que terão força de decisão irrecorrível, e somente poderão ser impugnados a partir de ação rescisória, assim destaca: "No caso de conciliação, o termo que for lavrado valerá como decisão irrecorrível, salvo para a Previdência Social quanto às contribuições que lhe forem devidas".

No artigo 784 do CPC estão elencados os demais títulos extrajudiciais reconhecidos no âmbito da justiça comum, mas que também serão reconhecidos na seara trabalhista quando estiverem presentes em alguma relação de trabalho. Assim, Leite (2016) destaca:

Os demais títulos extrajudiciais previstos no Novo CPC (art. 784), tais como letras de câmbio, cheques, notas promissórias, duplicatas etc. ainda carecem de força executiva no âmbito da Justiça do Trabalho, embora possam, não obstante, constituir documentos aptos para 
empolgar a propositura da ação monitória, desde que, é claro, a formação dos referidos títulos tenha origem na relação empregatícia ou relação de trabalho cuja ação correspondente tenha sido transferida para a competência da Justiça Laboral.

Mais especificamente quanto à natureza do processo de execução, atualmente predomina o sincretismo processual. A referida modalidade encontra respaldo no processo civil, e diferencia o processo de execução do cumprimento de sentença, já que a aplicabilidade de um ou de outro irá depender do título em que se constituem.

O cumprimento de sentença, consequência do sincretismo processual, nada mais é do que uma fase processual posterior à sentença, quando no lugar de se instaurar um novo processo para a execução do título, utiliza-se do mesmo processo para dar seguimento à ação. Nesse sentido, Leite (2016) explana:

Houve, assim, uma substancial revolução no $\mathrm{CPC} / 73$, no particular, que implicou o desaparecimento do "processo de execução de título judicial" e o surgimento de uma "fase de cumprimento da sentença" dentro do próprio processo de conhecimento, uma vez que a sentença deixou de ser $\mathrm{o}$ ato pelo qual o juiz esgotaria a sua função jurisdicional.

Em contrapartida, a CLT não possui distinção e nem especificação quanto à aplicabilidade de um procedimento ou outro, destinando os mesmos artigos para a fundamentação de ambos. Nas palavras de Leite (2016): “A CLT, como se sabe, dedica indistintamente os artigos 876 a 892 tanto ao cumprimento da sentença quanto à execução de título executivo extrajudicial".

Anteriormente, na antiga legislação, predominava a aplicação do processo de execução autônomo para qualquer título, independentemente se ele estava fundado em título executivo judicial ou extrajudicial. Assim, dada a sentença, instaurava-se um novo processo, o de execução, para que o credor tivesse o seu crédito adimplido, independentemente, inclusive da natureza da prestação.

Para os autores Rodrigues et al. (2016) a alteração veio justamente a partir do fortalecimento do princípio da celeridade processual, quando o Brasil aderiu à Convenção Americana de Direitos Humanos. A adesão ocorreu em 1992, internalizando a máxima de cumprimento de prazos razoáveis pelo juiz ou tribunal competente.

Atualmente, tanto no ordenamento civil quanto no trabalhista, encontra-se perfeitamente consolidado o entendimento pela aplicação do princípio. Isso foi de relevante importância para a evolução legislativa e surgimento do processo sincrético.

Assim, em razão da efetivação do princípio, os títulos executivos judiciais possuem o condão de promover a execução imediata, a partir da fase de cumprimento de sentença, e poderão fundar-se em execução provisória ou definitiva. Em contrapartida, os títulos executivos extrajudiciais possuem executividade a partir da instauração do processo de execução, sendo ela autônoma e definitiva.

Dentre os títulos executivos judiciais, é a sentença judicial transitada em julgado que possui o condão de iniciar a execução definitiva, já que ela visa atender a satisfação do credor de forma precisa e permanente. Tais atributos só nascerão a partir do trânsito em julgado, quando será encerrada a discussão em relação à materialidade do objeto do título.

Já o cumprimento provisório somente far-se-á quando ainda não ocorreu o trânsito em julgado da sentença, quando pender recurso sem o efeito suspensivo. Sobre as peculiaridades do cumprimento 
provisório, Gonçalves (2018) explana:

[Ela] corre por conta e risco do credor, que assume a responsabilidade pela reversão do julgado, pois ainda há recurso pendente. Caso a sentença seja reformada, cumprir-lhe-á ressarcir os danos que causou, o que prescinde de prova de culpa.

$[\ldots]$

Caso haja a reversão, seja pela reforma ou pela anulação da sentença, as partes serão repostas ao status quo ante, e os danos serão liquidados nos mesmos autos;

O cumprimento provisório de sentença, tal como o definitivo, realiza-se nos autos em que o título foi constituído. Mas, se eles encontram-se em órgão ad quem para a apreciação do recurso, se o processo não for eletrônico, há necessidade de novos autos, constituídos pela petição que dá início à fase de cumprimento de sentença, acompanhada das peças enumeradas no artigo 522, parágrafo único do CPC;

No cumprimento provisório, o credor deve prestar caução, mas apenas para o levantamento de depósito em dinheiro e a prática de atos que importem transferência de posse ou alienação de propriedade ou de outro direito real, ou dos quais possa resultar grave dano ao executado.

Dessa forma, o título será executado seguindo as regras de competência previstas nos artigos 877 e

877-A da CLT. A competência para a execução das decisões é do juiz ou presidente do tribunal que julgou a ação, seguindo as regras dos artigos 650 a 652 da Lei Trabalhista, sendo a aplicação das regras estendida para os títulos extrajudiciais. Assim referem os artigos 877 e 877-A da CLT:

Art. 877 - É competente para a execução das decisões o Juiz ou Presidente do Tribunal que tiver conciliado ou julgado originariamente o dissídio.

Art. 877-A - É competente para a execução de título executivo extrajudicial o juiz que teria competência para o processo de conhecimento relativo à matéria. (BRASIL, 1943)

Entretanto, tanto o cumprimento de sentença quanto a execução dependem de um impulso, não sendo, portanto, automáticas. Nesse ponto, a CLT difere do CPC, dispondo expressamente em seu artigo 878 a possibilidade de ser impulsionada pelas partes, de ofício pelo juiz ou até mesmo pelo presidente do tribunal. Esse último caso aplica-se nas situações em que as partes não estiverem acompanhadas de seu advogado.

O CPC não permite a interferência do juiz ou tribunal para a propositura da execução, devendo ser seguidas as suas disposições. Assim, incumbe àqueles citados no artigo 778 promover a execução em face daqueles que foram elencados no artigo 779. Ainda, quanto ao executado em ação de ressarcimento, merece destaque as observações de Gonçalves (2018):

O patrão responde objetivamente pelos danos causados pelo empregado, no exercício de suas atividades. A vítima de danos poderá ajuizar ação de ressarcimento contra o empregado, o empregador ou contra ambos, em litisconsórcio facultativo.

Mas se ajuizá-la só contra o empregado, a sentença só condenará a este. Só será possível executá-lo, não o empregador. Para que este seja executado, é necessário que tenha sido demandado também, e que a sentença o tenha incluído na condenação.

Tratando-se do cumprimento de sentença, o artigo 513 do CPC restringe a solicitação do requerimento ao exequente. Assim destaca o artigo:

O cumprimento da sentença será feito segundo as regras deste Título, observando-se, no que couber e conforme a natureza da obrigação, o disposto no Livro II da Parte Especial deste Código.

$\S 1$ O O cumprimento da sentença que reconhece o dever de pagar quantia, provisório ou definitivo, far-se-á a requerimento do exequente. 
[...] § 5 o O cumprimento da sentença não poderá ser promovido em face do fiador, do coobrigado ou do corresponsável que não tiver participado da fase de conhecimento. (BRASIL, 2015)

Nesse sentido, a referida diferença entre a instauração da fase de cumprimento de sentença trabalhista e a de cumprimento de sentença civilista se faz de grande importância, já que a partir dela se percebem caminhos processuais diversos. 0 artigo 884, embasado no artigo 765 da CLT, por tratar da execução de títulos de natureza alimentar, visa a atividade mais célere da justiça do trabalho, simplificando os procedimentos e possibilitando, subsidiariamente, a iniciativa por outros agentes.

A autora Fabíola Silva Carvalho $(2019$, n. p.) defende o entendimento, destacando o verdadeiro sentido do artigo 765 da CLT e os seus reflexos em outras fases do processo. Assim explana:

Na realidade, verifica-se que a ideia do art. 765 da CLT é deixar claro que o magistrado não é um mero expectador, mas cooperador e fiscal do curso processual, devendo zelar pelo regular andamento do processo e pelo esclarecimento dos fatos, sendo-lhe permitido, por exemplo, determinar pesquisa por meio de alguma ferramenta eletrônica ainda que a parte tenha requerido a expedição de ofício com o mesmo fim, ou, na instrução de um incidente de desconsideração da personalidade jurídica, se entender necessário, ouvir testemunhas do Juízo (referidas nos depoimentos das partes ou das testemunhas).

Tal fundamento jurídico destaca a possibilidade da atuação jurisdicional mais livre e efetiva, possibilitando que ao juiz seja permitida maiores contribuições para o seu julgamento mais imparcial e consagrado na justiça.

Nesse sentido, é importante que tanto as partes quanto o juiz estejam atentos na movimentação dos bens do executado, já que estão sujeitos à execução e à responsabilidade patrimonial todos os bens do devedor, exceto os impenhoráveis. É esse o entendimento extraído da leitura do artigo 789 do CPC, que assegura a responsabilidade atribuída aos bens presentes e futuros do devedor. Assim, sobre o entendimento do referido artigo, Gonçalves (2018) explana:

Em princípio, todos [os bens do devedor] estão sujeitos, os que existiam no momento em que a obrigação foi contraída e os que não existiam ainda, e só vieram a ser adquiridos posteriormente, sejam eles corpóreos ou incorpóreos, desde que tenham valor econômico.

Em contrapartida, o CPC, em seu artigo 833, resguarda alguns bens como sendo impenhoráveis, restringindo, portanto, a penhora. Portanto, todos os bens do devedor estarão sujeitos à execução, exceto aqueles previstos no artigo 833 , os impenhoráveis.

Diante do exposto, em conformidade com as interpretações dos autores supracitados, percebe-se que as previsões normativas existentes normalmente tendem a facilitar a execução nas hipóteses em que o credor seja detentor de bens, o que acaba assegurando a execução.

Porém, nos casos em que o devedor já não mais possui patrimônio para assegurar a execução, o credor deverá socorrer-se de outros meios processuais. Quanto a essas medidas, fazem parte de estudo posterior ao presente trabalho, cabendo orientações, pesquisas e amparo legislativo e jurisprudencial.

\section{CONCLUSÕES}

A construção histórica dos direitos fundamentais da classe trabalhadora foi marcada de acirradas lutas e movimentações sociais, que visavam a devida implementação de prerrogativas que proporcionassem 
uma vida mais digna, segura, igualitária e saudável. No entanto, não somente por perfazerem a égide do aparato legislativo, mas por impulsionarem a adequação do direito à progressão humana, o que se evidencia é que, de forma alguma, essas moções chegaram ao fim.

Do contrário, apresentando uma conotação positiva para a transcursão da evolução social, nesse cenário possuem por estigma a emergência pela tutela jurisdicional efetiva. Para tanto, deve ser levado em consideração que a eficácia da execução está atrelada, muitas vezes, à coerção imposta em face do executado, já que a penalidade imposta traz consequências drásticas, como no caso do devedor de alimentos, cuja penalidade extrapola os limites do patrimônio e acarreta prisão civil. O devedor se obriga a pagar em virtude da sanção que lhe é imposta, ela opera como fator de eficaz persuasão.

Assim, consonantemente, é possível compreender que, na verdade, a relutância do devedor em adimplir a obrigação transfigurou-se em protótipo, e não mais ressalvas aplicáveis em sentido estrito. Na prática jurídica, prevalece o entendimento de que as obrigações contidas na decisão não o serão por hora satisfeitos assim que proferidas, mas apenas no caso de não se obter êxito nas tentativas de esquivar-se.

Visto isso, em muitos desses casos em que a tutela jurídica não resta devidamente resguardada, o resultado almejado desde a propositura da demanda que não se consuma, acarreta a violação da tutela constitucional inerente aos direitos individuais e sociais. Assim, a inexequibilidade daquele título originado da demanda ou da via extrajudicial, culmina na ineficácia da persecução processual.

Parcela dessa ineficiência é resultante da carência coercitiva e cogente da execução em face de devedor insolvente, que se camufla por detrás de falcatruas e jogadas estratégicas a fim de esquivar-se de sua obrigação. Formula-se aí, um obstáculo cujos institutos cabíveis nem sempre culminam em resultados satisfatórios.

Ademais, cumpre ressaltar que a função social do trabalho, mais especificamente dos rendimentos provenientes dele, possui caráter alimentar, o que reforça ainda mais o dever de cumprimento. A necessidade urgente pela eficácia imediata é embasada nessas características essenciais presentes no título, sendo que a efetivação também recai sobre a vulnerabilidade do trabalhador.

\section{REFERÊNCIAS}

ARAÚJO, J.. A efetividade da decisão judicial trabalhista como tutela jurídica aos direitos fundamentais. Revista Eletrônica UNIFACS, n.213, p.1-30, 2018.

ASSIS, R. L. B. D.. A valorização do negociado sobre o legislado na reforma trabalhista. Revista Eletrônica do Tribunal Regional do Trabalho da Bahia, v.5, n.9, 2017.

BONAVIDES, P.. Curso de Direito Constitucional. 19 ed. São Paulo: Malheiros, 2006.

BRASIL. Constituição Federal de 1988. Brasília: DOU, 1988

BRASIL. Código de Processo Civil: lei n. 13.105, de 16 de março de 2015. Brasília: DOU, 2015.

BRASIL. Lei n. 5.452, de 01 de maio de 1943. Brasília: DOU 1943.
CADEMARTORI, L. H. U.. Os fundamentos de legitimidade do estado constitucional: as análises de weber e habermas. In: Temas de política e direito constitucional contemporâneos. Florianópolis: Momento Atual, 2004.

CAPPELLETTI, M.; BRYANT, G.. Acesso à Justiça. Porto Alegre, 2002.

CARVALHO, F. S.. Status da parte autora na execução trabalhista pós-reforma: um panorama geral. Revista Jus Navigandi, Teresina, v.24, n.5812, 2019

CLAUS, B.-H. S.. A execução trabalhista não se submete ao princípio da execução menos gravosa: um olhar contemporâneo para a execução trabalhista efetiva. Curitiba: Juslaboris, 2014. 
CINTRA, A. C. A.; GRINOVER, A. P.; DINAMARCO, C. R.. Teoria geral do processo. 11 ed. São Paulo: Malheiros, 1995.

GONÇALVES, M. V. R.. Direito processual civil esquematizado. São Paulo: Saraiva Educação, 2018.

GUIMARÃES, A. S.. A importância dos princípios jurídicos no processo de interpretação constitucional. São Paulo: LTr, 2003.

LEITE, C. H. B.. Cumprimento da sentença no Novo CPC: Aspectos gerais e a aplicação no direto processual do trabalho. Belo Horizonte: Juslaboris, 2016.

MARQUES, L. R.. Alguns pontos polêmicos da aplicação subsidiária do Código de Processo Civil na Execução Trabalhista. Porto Alegre: Conteúdo PUC/RS, 2018.

MARQUES, R. E. S. R.. Prazo de decadência das contribuições previdenciárias executadas de ofício na justiça do trabalho. IBET, 2019.
PORTANOVA, R.. Princípios do Processo Civil. 6 ed. Porto Alegre: Livraria do Advogado, 2005.

PORTO, P. R. F.. Direitos Fundamentais Sociais. Porto Alegre: Livraria do Advogado, 2006.

RODRIGUES, H. W.; LAMY, E. A.. Teoria geral do processo. São Paulo: Atlas, 2016.

SARAIVA, R.. Curso de Direito Processual do Trabalho. 2 ed São Paulo: Método, 2005.

SCHIAVI, M.. Execução no processo do trabalho. 2 ed. São Paulo: LTr, 2010

SCHIAVI, M.. A reforma trabalhista e o processo do trabalho. São Paulo: LTr, 2018.

SEABRA NETO, W.. Princípios do direito do trabalho. Direito do Trabalho-Empreendedorismo Jurídico. Seabraneto, 2019.

A CBPC - Companhia Brasileira de Produção Científica (CNPJ: 11.221.422/0001-03) detém os direitos materiais desta publicação. Os direitos referem-se à publicação do trabalho em qualquer parte do mundo, incluindo os direitos às renovações, expansões e disseminações da contribuição, bem como outros direitos subsidiários. Todos os trabalhos publicados eletronicamente poderão posteriormente ser publicados em coletâneas impressas sob coordenação da Sustenere Publishing, da Companhia Brasileira de Produção Científica e seus parceiros autorizados. Os (as) autores (as) preservam os direitos autorais, mas não têm permissão para a publicação da contribuição em outro meio, impresso ou digital, em português ou em tradução. 